Article

\title{
Strategic Analysis of the Automation of Container Port Terminals through BOT (Business Observation Tool)
}

\author{
Alberto Camarero Orive * ${ }^{\mathbb{C}}$, José Ignacio Parra Santiago ${ }^{\circledR}$, \\ María Magdalena Esteban-Infantes Corral and Nicoletta González-Cancelas $\mathbb{D}$ \\ Department of Transport Engineering, Urban and Regional Planning; Universidad Politécnica de Madrid, \\ 28040 Madrid, Spain; joseignacio.parra.santiago@alumnos.upm.es (J.I.P.S.); \\ magdalena.estebanic@gmail.com (M.M.E.-I.C.); nicoleta.gcancelas@upm.es (N.G.-C.) \\ * Correspondence: alberto.camarero@upm.es
}

Received: 18 December 2019; Accepted: 31 January 2020; Published: 4 February 2020

\begin{abstract}
The port system is immersed in a process of digital transformation towards the concept of Ports 4.0, under the new regulatory and connectivity requirements that are expected of them. As a result of the changes that the industrial revolution 4.0 is imposing, based on new information technologies and the change of energy model, the electrification of modes of transport from alternative energies and the total digitalization of the processes is occurring. This conversion to digital, intelligent, and green ports requires the implementation of the new technologies offered by the market. The inclusion of these enabling tools has allowed the development of automated terminals under a functional approach. This article aims to offer the responsible entities a new methodology (BOT) that allows them to successfully undertake the automation of terminals, taking into account the reality of the conditions of the environment in which they are developed. By quantifying the factors that facilitate or impede implementation, it will be possible to determine the strategy to be followed and the necessary measures to be adopted in the project; constituting, therefore, a novel management and planning tool.
\end{abstract}

Keywords: container automated terminals; BOT; strategy; automation

\section{Introduction}

Automated container port terminals have proliferated since the Europe Container Terminals (ECT) in Rotterdam, which began to be automated in 1984 [1]. Automation carried out in existing and operational terminals (brownfield) and in new terminals (greenfield), such as Total Terminal International (TTI) Algeciras, inaugurated in 2010, found a solution adopted in the Global Container Terminal (New York/New Yersey). Thus, there are currently around 60 automated terminals in the world, mainly in Europe and Asia, with forecasts to reach 200 in the next 5 years [2], among which are the new container terminal at the port of Valencia and the incorporation of eight automated RTG (Rubber Tyred Gantry Crane) in the container terminal of Belfast (BCT), turning it into a semi-automated terminal.

Although the automation process is not exclusive to container terminals, the intrinsic characteristics of these terminals, such as their high degree of specialization and standardization (both in the transport element and in the way of handling the goods), and technological advances have protected the development of a high degree of automation in the equipment and processes of these facilities [3]. These characteristics, together with the increase in competition in the port industry, have encouraged the development of automated terminals with the aim of reducing operating costs (OPEX), mainly in terms of labor, and seeking improvements in terms of productivity, safety, and environmental sustainability. 
However, it is also true that in some terminals the productivity can be reduced after automation due to inadequate phase-in.

Therefore, the objectives of this article are to use a methodology (Business Observation Tool (BOT)) to help automated terminals develop their short- and long-term strategies and to answer research-related questions, such as "What characteristics are needed to be considered for the implementation of automation in a terminal?".

\section{Types of Automated Terminals}

The first step of the digital transformation (first generation) was taken in the 1980s with the emergence of electronic data interchange (EDI) systems and the development of the first terminal operating systems (TOS) [4], laying the foundation for automated terminal planning. The adoption by operators of new handling technologies (sensors and laser technologies) and the integration of data obtained from them led to the establishment of automated terminals in the 1990s and in 2000 (second generation) [5]. The performance of the ports of Hong Kong and Singapore is close to meeting the definition of fifth generation criteria. On the contrary, in light of the majority of the evaluation criteria's performance, the ports of Busan and Shanghai are still behind the 5GP stage [6].

The concept of "automated terminal" was coined after the commissioning, in 1993, of ECT Delta Terminal in the Port of Rotterdam, referring to the terminal in which operations relating to yard movements, storage equipment, and quay-patio interconnection have been automated [7].

According to the different degrees of automation of the main movements (yard, dock-yard) the terminals are classified into automated, semi-automated and manual terminals. A semi-automated terminal will be one in which the storage or interconnection equipment is automated. However, the term "semi-automatization" is also associated with the management of equipment by assisted control or the systematization of some of the functions of the equipment by means of minor or partial automatizations [3].

Following this classical classification, Figure 1 presents the main automated terminals, which are numbered according to the chronological order of operation. Based on this chronology, Table 1 shows the automation technology and the handling equipment used by them, such as ARMG (Automated Rail Mounted Gantry), C-ARMG (Cantilever ARMG), ASC (Automated Stacking Crane), ARTG (Automated Rubber Trued Gantry Crane), or AGV (Automated Guide Vehicle).

The terminal column represents the name (company) and country of the study terminal; the equipment column represents the set of equipment that make up the terminal; and the type column represents the type of terminal according to its degree of automation, (A) being the fully automated and (S) being the semi-automated.

The traditional conception of an automated terminal responds to the use of automated equipment mainly in the storage subsystem and in the interconnection subsystem. However, the delivery and reception system is where the highest degree of automation has been implemented, particularly in processes such as container and truck identification or weighing [8].

Finally, the loading and unloading system, in which the docking subsystem may be included, is the least automated. Although there are terminals that use STS cranes (Ship To Shore gantry crane) in the ship-to-shore operation, as is the case in the Rotterdam World gateway and APM Terminal Maasvlakte II terminals in Rotterdam [9]. Similarly, mooring is also subject to the replacement of moorers through the use of vacuum systems or adhesion to the hull, an example of this system was installed, for the first time in Europe, in 2013 in a mineral terminal in the port of Narvik, Norway. 


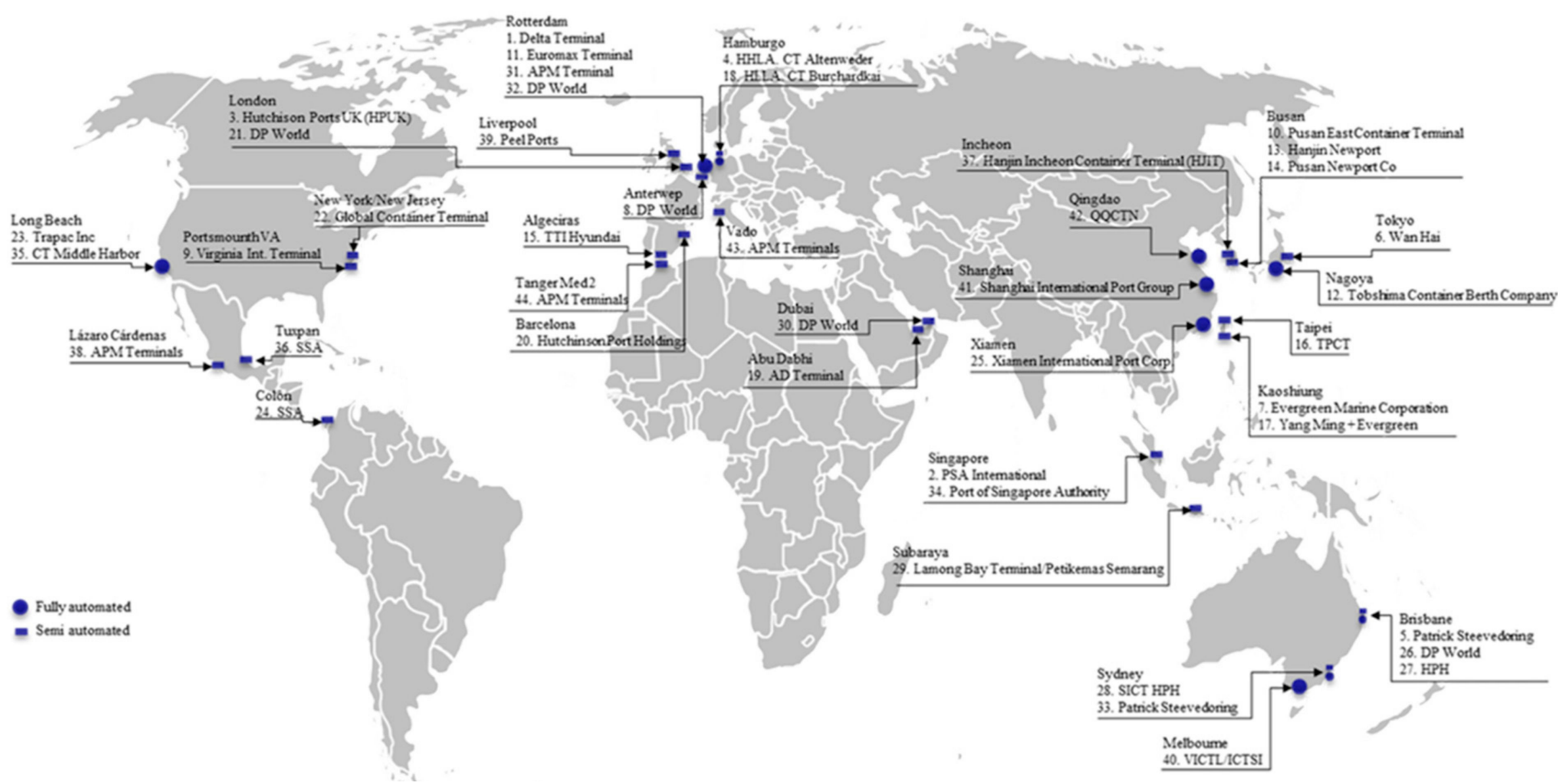

Figure 1. Main automated and semi-automated terminals in the world. 
Table 1. Main automated (A) and semi-automated (S) terminals in chronological order.

\begin{tabular}{|c|c|c|}
\hline Terminal & Equipment & Type \\
\hline ECT Europa Container Terminal -Rotterdam. Delta Terminal (1993) & 137 ARMG / AGV & A \\
\hline PSA International—Singapur. Pasir Panjang Terminal (1997) & $\begin{array}{c}15 \mathrm{OHBC} \\
\text { Manual tractor (M.T.) + chassis }\end{array}$ & $\mathrm{S}^{*}$ \\
\hline Hutchison Ports UK (HPUK)—London Thamesport (2000) & $\begin{array}{l}18 \text { ARMG } \\
\text { M.T. + chassis }\end{array}$ & S \\
\hline HHLA—Hamburgo. CT Altenwerder (CTA) (2001) & 52 ARMG / AGV & A \\
\hline Patrick Steevedoring_Brisbane. Fishermans Island Terminal (2002) & 27 Auto SC / Auto SC & A \\
\hline Wan Hai-Tokyo. Ohi Terminal (2003/06) & $\begin{array}{l}\text { 8CARMG } \\
\text { M.T. + chassis }\end{array}$ & S \\
\hline $\begin{array}{l}\text { Evergreen Marine Corporation—Kaoshiung. Evergreen Marine Terminal } \\
\qquad(2005)\end{array}$ & $\begin{array}{l}\text { 6CARMG } \\
\text { M.T. + chassis }\end{array}$ & S \\
\hline DP World-Amberes Antwerp Gateway (2007) & 14 ARMG / ShC manual & S \\
\hline $\begin{array}{l}\text { Virginia International Terminal (VIT)_Portsmouth. VA Virginia int. } \\
\text { Gateway (2007) }\end{array}$ & $\begin{array}{c}30 \text { ARMG } \\
\text { Manual cassettes }\end{array}$ & S \\
\hline Pusan East Container Terminal—Busan. Korean Express Brusan CT (2007) & $\begin{array}{l}\text { 6 ARMG } \\
\text { M.T. + chassis }\end{array}$ & S \\
\hline ECT Europa Container Terminal—Rotterdam. Euromax terminal (2008) & 58 ARMG / AGV & A \\
\hline $\begin{array}{l}\text { Tobshima container berth (TCB) company-Nagoya. Tobishima Pier South } \\
\qquad(2008)\end{array}$ & $\begin{array}{l}12 \text { ARTG } \\
\text { AGV }\end{array}$ & A \\
\hline $\begin{array}{l}\text { Hanjin Newport—Hyundai Merchant Marine—Busan. Pusan Newport } \\
\qquad(2009 / 10)\end{array}$ & $\begin{array}{l}41+36 \text { ARMG } \\
\text { M.T. + chassis }\end{array}$ & S \\
\hline Pusan Newport Co (DP World)—Busan. Pusan Newport (2009/12) & 32 + 38 CARMGM.T. + chassis & S \\
\hline TTI Hyunday_Algeciras. Isla Verde (2010) & 32 ARMG / ShC manual & S \\
\hline TPCT—Taipei Port Container Terminal (2010) & $\begin{array}{l}40 \text { CARMG } \\
\text { M.T. + chassis }\end{array}$ & S \\
\hline $\begin{array}{l}\text { Yang Ming+Evergreen-Kaoshiung. Kao Ming Container Terminal } \\
(2010 / 11)\end{array}$ & $\begin{array}{l}22+40 \text { dual CARMG } \\
\text { M.T. + chassis }\end{array}$ & S \\
\hline HHLA-Hamburgo. CR Burchardkai (CTB) (2010/17) & $\begin{array}{l}15-12 \text { ARMG } \\
\text { SHC manual }\end{array}$ & S \\
\hline AD Terminals_Abu Dhabi. Khalifa Container Terminal (2012) & 42 ARMG / ShC & S \\
\hline Hutchinson Port Holdings-Barcelona. BEST (2012) & 48 ARMG / ShC & S \\
\hline DP World-London Gateway 1,2/3 (2013/2016) & $40+20$ ARMG / ShC & S \\
\hline Global container Terminal—New York/New Jersey. Global Terminals (2014) & $\begin{array}{l}20 \text { ARMG } \\
\text { ShC }\end{array}$ & S \\
\hline Trapac Inc - Long Beach. Trapac (2014) & 27 ARMG/ ShC & A \\
\hline SSA—Colón Manzanillo Int. Terminal (2014) & 22 ARMG & S \\
\hline Xiamen International Port Corp-Xiamen. Halcang + Fuijang (2014) & 16 ARMG / 18 AGV & A \\
\hline DP WOrld-Brisbane (2014) & 14 ARMG / ShC & S \\
\hline HPH—Brisbane Container Terminal (2014) & 12 ARMG / ShC & $\mathrm{S}$ \\
\hline SICT HPH—Sydney Inter. Container Terminal (2014) & 12 ARMG / ShC & $\mathrm{S}$ \\
\hline $\begin{array}{l}\text { Lamong Bay Terminal/Petikemas Semarang—Surabaya. Pelindo III } \\
\qquad(2014 / 16)\end{array}$ & 20 ARMG + 11 ARTG & S \\
\hline DP World-Dubai. Jebel Ali Container Terminal 3/4 (2014/18) & $60+35$ ARMG & $\mathrm{S}$ \\
\hline APM Terminal—Rotterddam. APMT Maaskvlakte II (2015) & $\begin{array}{l}54 \text { ARGM } \\
\text { 36+Lift AGVs }\end{array}$ & A \\
\hline DP/World—Rotterdam World Gateway (2015) & 32 ARMG / AGV & A \\
\hline Patrick Steevedoring_Sydney Autostrad (2015) & 44 AutoSC / AutoSC & $\mathrm{A}$ \\
\hline Port of Singapur Authority—PSA PPT 3-1a T\%, 3-1b, 3-2b (2015/2016) & $\begin{array}{l}\text { 22+34+72 CARMG } \\
\text { M.T. + chassis }\end{array}$ & $\mathrm{S}^{*}$ \\
\hline
\end{tabular}


Table 1. Cont.

\begin{tabular}{ccc}
\hline Terminal & Equipment & Type \\
\hline Long Beach CT Inc.-CT Middle Harbor (2016) & 32 ARMG & A \\
\hline SSA Mexico-Tuxpan Port Terminal (TPT) (2016) & 8 ASC / M.T. + chassis & S \\
\hline Hanjin Incheon Container Terminal-Incheon (2016) & 14 ARMG & S \\
\hline APM Terminals - Veracruz Lázaro Cárdenas T2 (2016) & 22 ARMG \\
\hline Peel Ports-Liverpool2 (2016) & 22 CARMG & A \\
\hline VICTCL/ICTSI-Melbourne. Victoria Int. CT (2016/17) & 32 ARMG / 11 AutoShC & A \\
\hline QQhangai International Port Group-Shangai. Yangshan Fase 4 (2017) & 40 ARMG / 50 AGV & A \\
\hline APM Terminals-VADO. Liguere (2019) & 38 ARMG / 38 AGV & S \\
\hline APM Terminals-Tanger Med 2 (2019) & 21 ARMG & M.T. + chassis \\
\hline
\end{tabular}

* Ports with semi-automatic terminals but with equipment they use for experiments. Source: Own elaboration with data from "Puertos del Estado".

A paper investigates crane scheduling problems for a new type of automated container terminal system, which is based on multi-storey frame bridges. For the new design concept, the paper studies how to schedule two types of cranes, i.e., quay cranes and bridge cranes that transfer containers between different storeys [10]. Another paper makes an explorative study to identify the challenges and opportunity for it to be applied in transshipment hubs [11].

Most of the operational problems in container terminals are strongly interconnected. A paper study of the integrated Berth Allocation and Quay Crane Assignment Problem in seaport container terminals can be found in [12].

\section{Methodology}

The analysis and diagnosis of automated container terminals has been approached using the BOT (Business Observation Tool) model. It is a management tool, an alternative to PESTEL (Political, Economic, Social, Technological, Ecological, Legal), which allows, through observation, for the initiation and recognition of those minimum elements that must be considered to formulate and implement the business idea.

The model is based on the establishment of four main scenarios: Motivations and Capacities (resources) to advance, Establishment of the working group, Characterize and understand the development environment, and Macro-environment analysis; through which, the boundary is obtained and the conditions of the BOT analysis are carried out, identifying the conditioning factors of the automation in the terminals and requirements that must be raised to achieve automation in the ports.

In this article, the BOT. methodology has been used as an alternative to traditional analyses such as PESTEL or the development of the SWOT (Strength-Weaknesses-Opportunities-Threats) matrix. The use of this tool allows us to establish the current scenario on which to act to achieve a correct implementation of port terminals, addressing and considering both micro and macro environmental aspects.

This article is the first inclusion of the BOT methodology in the port sector. The possibility of being used as a tool for strategic decision making has been cited in the hotel sector to study its economic and financial viability [13] and to analyze the inherent risks; and in the construction of an entrepreneurial culture in Ecuador [14].

The BOT. is a tool that is widely used in the business sector, but can be applied to any sector, provided that the methodology defined by the BOT. is used correctly. It is therefore applicable in the port sector when terminal operators make decisions to automate (to a greater or lesser degree) their port terminals. 


\subsection{Step 1: BOT Analysis}

Based on the state of the art, description of the BOT analysis in a figure, with the four qualities to be studied within the analysis and how they relate to each other (Figure 2).

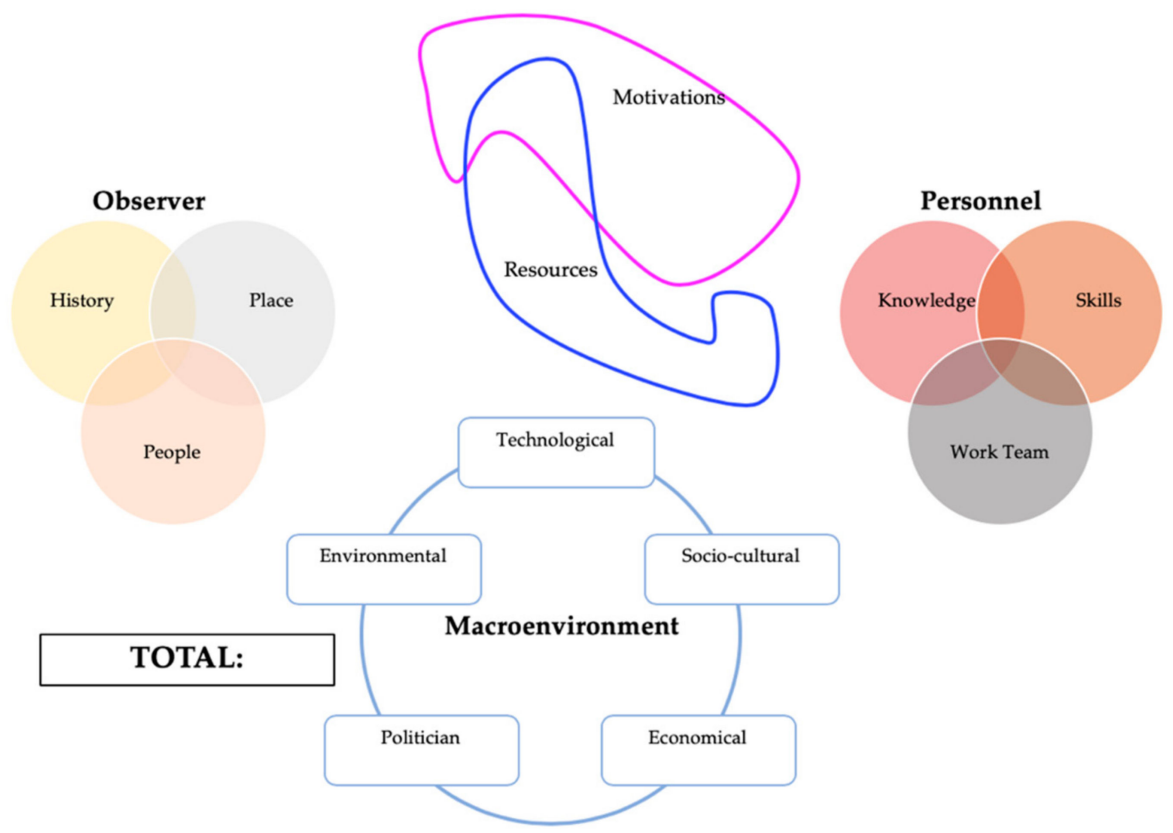

Figure 2. Business Observation Tool (BOT) Analysis. Source: own elaboration based on slideshare.net Álvaro Morales.

\subsubsection{Motivations and Resources to Advance}

Motivations and resources are usually the most important scenarios. Therefore, they usually allow the viability of the project and to be able to execute it with a high impact. The development of the project requires determining the motivation to opt for such a solution and the study of available resources for which the following questions must be answered: What is the motivation to develop the project and do it with a high impact? What resources are available to develop this project?

\subsubsection{Establishment of the Working Team}

Through the analysis of the composition of the labour network, taking into account both the knowledge and skills of each agent involved (port operators and agents related to port operations) and the shortcomings they may have to carry out the plan, the work teams are configured, determining the needs and requirements of the team members, in order to achieve the success of the project. In other words, this scenario must respond to What are and how can the talents of each team member be harnessed in favor of the project?

\subsubsection{Characterize and Understand the Development Environment}

The understanding of the environment, thanks to the determination of those external factors that indicate its implementation and development, facilitates the establishment of the implementation mechanism and strategies. Their determination is addressed by answering the following question: What external characteristics to the project can alter decisions and strategies formulated in the future?

\subsubsection{Macroenvironment Analysis}

The study of the macroenvironment, also known as the generic environment, is based on obtaining those technological, socio-cultural, economic, political and environmental factors that may condition 
or intervene in the achievement of the project: What characterizes the observed environment; and; How it can be used to favor the project?

\subsection{Step 2: Selection of Indicators}

Once the scenarios that make up the analysis have been completed, the indicators with the greatest impact on the business model are selected to measure the activity of the automated operations.

Table 2 presents the indicators selected to characterize the four scenarios.

Table 2. Definition of the characterization indicators based on BOT scenarios.

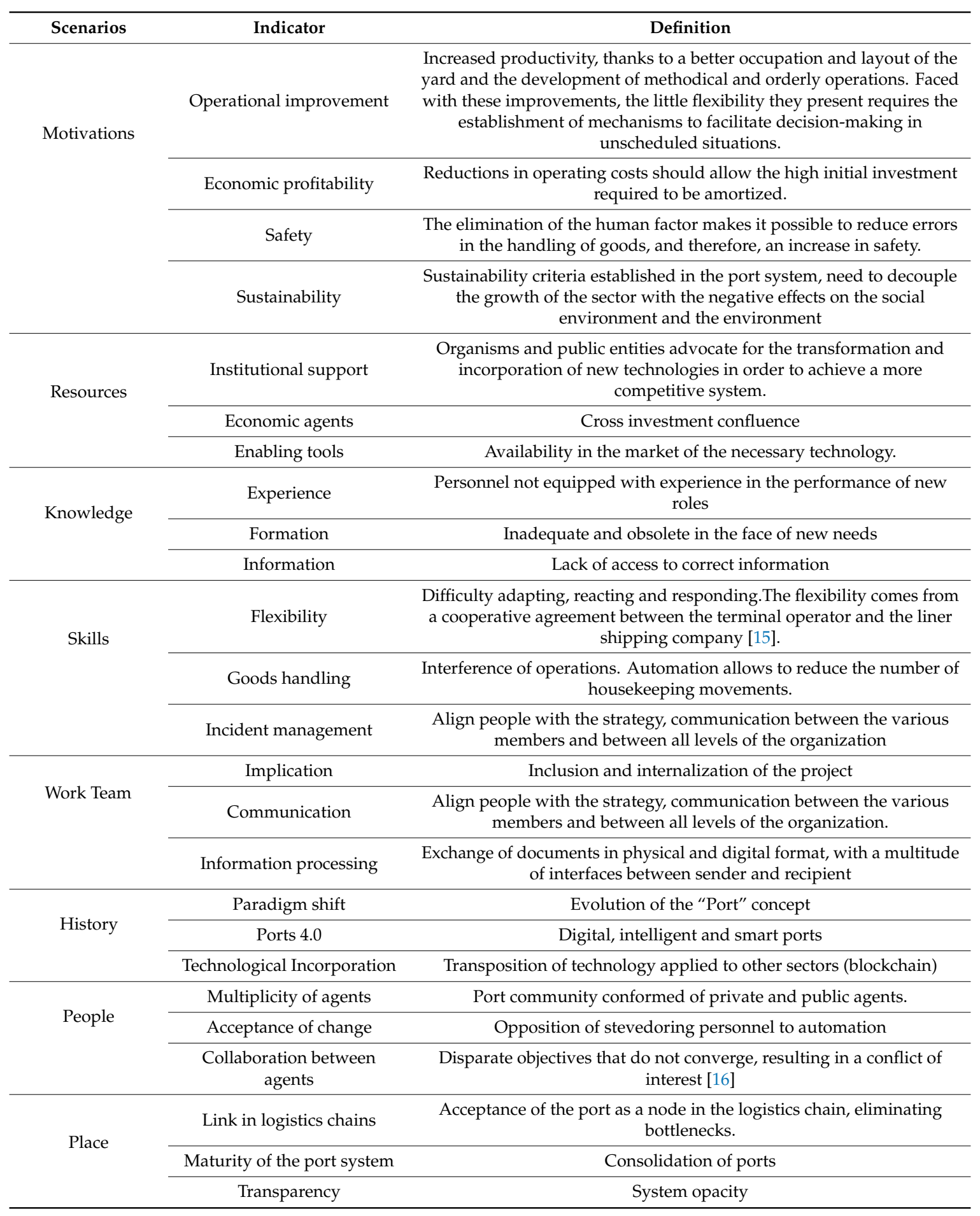


Table 2. Cont.

\begin{tabular}{|c|c|c|}
\hline Scenarios & Indicator & Definition \\
\hline \multirow{4}{*}{ Technological } & Technological maturity & Solid fundamentals and verified developed solutions \\
\hline & Obsolescence & Emergence of new technologies as a result of research \\
\hline & Implementation mechanisms & $\begin{array}{l}\text { Lack of protocols and methodology to facilitate the implementation of } \\
\text { technology }\end{array}$ \\
\hline & Research & $\begin{array}{l}\text { Research initiatives must be accompanied by pilot tests certifying their } \\
\text { adequacy. }\end{array}$ \\
\hline \multirow{3}{*}{ Socio-cultural } & Training of personnel & Unskilled personnel \\
\hline & $\begin{array}{l}\text { Support for trade union } \\
\text { strength }\end{array}$ & $\begin{array}{l}\text { The current union strength in the ports and their reluctance to change is } \\
\text { a handicap for the adoption of automated terminals. }\end{array}$ \\
\hline & Reconversion & $\begin{array}{l}\text { The change in the management model of the terminals implies a } \\
\text { reconversion of the workers to technological profiles }\end{array}$ \\
\hline \multirow[t]{2}{*}{ Environmental } & Decarbonization & $\begin{array}{l}\text { The European Environment Agency (EEA) [17] estimates that shipping } \\
\text { has increased its greenhouse gas emissions by } 22 \% \text { from } 1990 \text { to } 2016 . \\
\text { Faced with this increase, the OECD (Organization for Economic } \\
\text { Cooperation and Development) has established measures supported by } \\
\text { the use of new technologies to achieve the decarbonization of maritime } \\
\text { transport by } 2035 \text { [5]. }\end{array}$ \\
\hline & Reduction of externalities & $\begin{array}{l}\text { Negative externalities, such as congestion, accidents and pollution } \\
\text { (atmospheric, acoustic, and visual) can be mitigated with the } \\
\text { implementation of automated terminals due to the more rational use of } \\
\text { space, the use of electrical equipment, and the programming of removal } \\
\text { operations in such a way that they do not intervene in the operation of } \\
\text { the terminal. }\end{array}$ \\
\hline Political & Regulatory requirements & Hardening of regulations \\
\hline \multirow{3}{*}{ Economical } & Lobbies & $\begin{array}{l}\text { Faced with the possibility of a new economic slowdown and the risk of } \\
\text { implementing automated terminals, investments have been reduced. }\end{array}$ \\
\hline & Financing & Search for alternative financing \\
\hline & Community aid & European funding with high requirements for its granting. \\
\hline
\end{tabular}

\subsection{Step 3: Qualitative-Quantitative Analysis}

Qualitative-quantitative analysis will be carried out on the basis of the selected indicators. Depending on the scope or level of the achievement of each indicator considered, each indicator will be scored qualitatively and quantitatively. These scores will be made by a group of experts in the sector in which they score the indicator according to the ratio and impact required for automation:

- High degree of achievement: "High"—5

- Medium range: "Medium"-2.5

- Low range: "Low"-1

The quantification of each indicator and, therefore, of each scenario, through its weighting, forms the basis on which strategic decisions must be taken for the implementation and achievement of objectives. 


\section{Expected Results and Discussion}

\subsection{BOT Analysis}

\subsubsection{Motivations and Resources to Move Forward}

Ports are subject to new requirements in terms of sustainability, costs, safety, and efficiency. In order to meet these requirements and maintain their competitiveness, they must evolve and move towards the concept of Port 4.0. This conversion involves, among other measures, the automation of processes.

The automation of port terminals is motivated by the benefits obtained from this process, such as a reduction in operating costs (OPEX), mainly due to a reduction in the workforce, an increase in terminal safety, or environmental benefits, as these are terminals with a higher density of containers that make better use of space and operate with electrical equipment.

Additionally, there are high investment costs associated with automation compared with to traditional settings.

In order to carry out the automation of the processes, institutional support is available, as well as the desire of the Port Authorities and national and international bodies required to implement them, the interest of economic agents and operators in investing in new developments, and the tools and enabling technologies that the market offers to undertake the project.

\subsubsection{Establishment of the Working Group}

The achievement of the objectives lies in the involvement of the many agents, both public and private, in the fluidity of the data transmission between them, and in the processing and handling of this information. This requires a reconversion of the labor network, since the personnel do not have the necessary qualification and experience for the new technological developments.

\subsubsection{Characterize and Understand the Development Environment}

Since 2010 we have been in the third generation, which is based on a more efficient exchange of information and the integration of intelligent procedures, allowing a conversion of the concept "Smart port" to "Ports 4.0". (Connected ports with high digitalization and sensorization).

The transformation of the port system requires greater transparency [19] and collaboration between the agents involved, starting by assuming and internalizing the need for change and regeneration.

\subsubsection{Macro-Environment Analysis}

- Technological. The automation and rationalization of port procedures has been made possible by digitalization and the integration of information technologies (IT) and innovative information systems (IS). The dynamism of the technological industry requires the establishment of implementation mechanisms that allow the inclusion of the new tools available and adaptation to new developments arising from research, such as the inclusion of autonomous vessels [20].

- Socio-cultural. In a sector with an important trade union strength, the automation of the terminals causes a social conflict, as it implies a reduction in the traditional required labor force.

- Economical. The Spanish port system has established a plan to boost entrepreneurship for innovation in the port sector, endowed with a fund of 25 million euros [21]. On the other hand, the European Sea Ports Organization, ESPO, has developed the "Connect Europe" program (2021-2028), with the aim of financing new port developments. Within this program, it is estimated that European ports will have investment needs of around 48,000 million euros between 2018 and 2027, caused by external factors such as the growth of trade flows, new trends in the maritime industry, decarbonization, digitalization, automation, urban development, and security [22]. 
- Political. Political actors and institutions advocate the incorporation of automation in maritime transport.

- Environmental. The European Union aims to reduce greenhouse gas emissions [23] through a change in energy models, so decarbonization will be a key element for maritime transport [24].

\subsection{Qualitative-quantitative Analysis}

Based on the observed reality, we proceed, taking into account the degree of implementation, to score each selected indicator (Table 3).

Table 3 represents the score made in the Delphi panel by a group of six experts in the field, which is made up of members of the public, private, and $\mathrm{R}+\mathrm{D}+\mathrm{i}$ company. The experts had to score from 1 to 5 the importance of the indicator according to its importance within the study.

Figure 3 presents the results obtained for each scenario, which allows us to identify the aspects that require more attention.

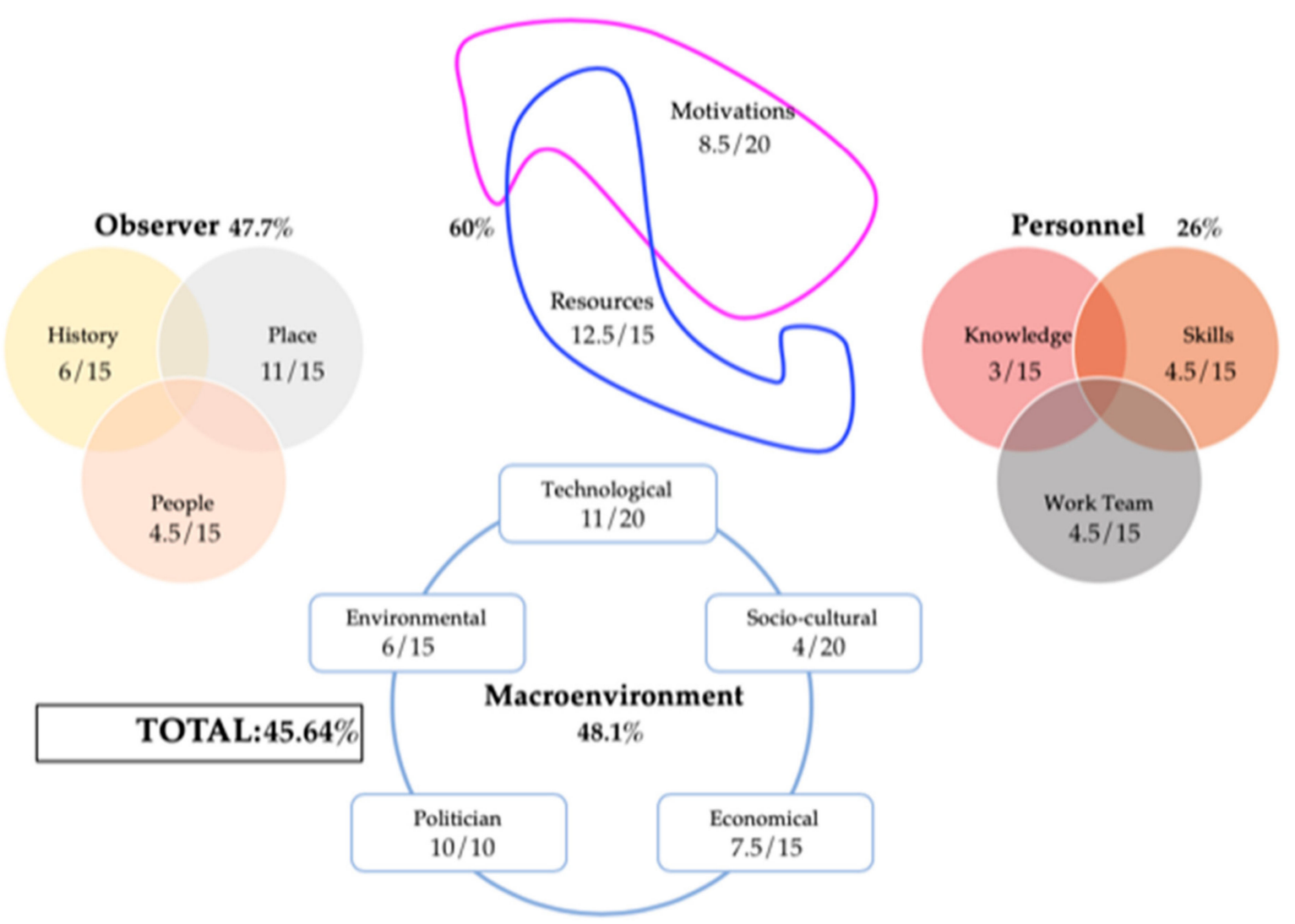

Figure 3. BOT analysis results. Source: Own elaboration based on slideshare.net Álvaro Morales. 
Table 3. Score of the indicators.

\begin{tabular}{|c|c|c|c|}
\hline sTAGE & Indicator & Qualitative & Quantitative \\
\hline \multirow{4}{*}{ Motivations } & Operational improvement & Medium & 2.5 \\
\hline & Economic profitability & Medium & 2.5 \\
\hline & Safety & Low & 1 \\
\hline & Sustainability & Medium & 2.5 \\
\hline \multirow{3}{*}{ Resources } & Institutional support & High & 5 \\
\hline & Economic agents & Medium & 2.5 \\
\hline & Enabling tools & High & 5 \\
\hline \multirow{3}{*}{ Knowledge } & Experience & Low & 1 \\
\hline & Formation & Low & 1 \\
\hline & Information & Low & 1 \\
\hline \multirow{3}{*}{ Skills } & Flexibility & Low & 1 \\
\hline & Goods handling & Medium & 2.5 \\
\hline & Incident management & Low & 1 \\
\hline \multirow{3}{*}{ Work Team } & Implication & Low & 1 \\
\hline & Communication & Low & 1 \\
\hline & Information processing & Medium & 2.5 \\
\hline \multirow{3}{*}{ History } & Paradigm shift & Medium & 2.5 \\
\hline & Ports 4.0 & Low & 1 \\
\hline & Technological Incorporation & Medium & 2.5 \\
\hline \multirow{3}{*}{ Place } & Link in logistics chains & High & 5 \\
\hline & Maturity of the port system & High & 5 \\
\hline & Transparency & Low & 1 \\
\hline \multirow{3}{*}{ People } & Multiplicity of agents & Medium & 2.5 \\
\hline & Acceptance of change & Low & 1 \\
\hline & Collaboration between agents & Low & 1 \\
\hline \multirow{4}{*}{ Technological } & Technological maturity & High & 5 \\
\hline & Obsolescence & Medium & 2.5 \\
\hline & Implementation mechanisms & Low & 1 \\
\hline & Research & Medium & 2.5 \\
\hline \multirow{4}{*}{ Socio-cultural } & Training of personnel & Low & 1 \\
\hline & Support for trade union strength & Low & 1 \\
\hline & Reconversion & Low & 1 \\
\hline & Safety & Low & 1 \\
\hline \multirow{3}{*}{ Economical } & Lobbies & Medium & 2.5 \\
\hline & Financing & Medium & 2.5 \\
\hline & Community aid & Medium & 2.5 \\
\hline \multirow{2}{*}{ Political } & Institutional Impulse & High & 5 \\
\hline & Regulatory requirements & High & 5 \\
\hline \multirow{3}{*}{ Environmental } & Decarbonization & Low & 1 \\
\hline & Reduction of externalities & Medium & 2.5 \\
\hline & Energy efficiency & Medium & 2.5 \\
\hline
\end{tabular}




\section{Conclusions}

In this article, the BOT methodology has been used as an alternative to traditional analyses, such as PESTEL or the development of the SWOT matrix. The use of this tool allows us to establish the current scenario on which to act to achieve a correct implementation of port terminals, addressing and considering both micro- and macro-environmental aspects.

The motivations and available resources are the fundamental axes for executing the project. Within this central scenario, a greater participation of economic agents must be achieved through transparency, so that, together with a regeneration of the personal scenario, the benefits derived from automation can be obtained.

The critical point of successful implementation is in socio-cultural factors. Complete automation will only be possible through dialogue and communication with trade unions, involving them in the project, and providing them with the information and training necessary for their retraining, so that workers acquire the necessary skills according to their capabilities.

As a conclusion, a global perspective map of the aspects considered in the implementation of automation in the terminals is presented. It indicates the current degree of incidence and the desired degree to carry out the project successfully. All this is presented in Figure 4.

\begin{tabular}{|c|c|c|c|}
\hline & TODAY & SHORT TERM & LONG TERM \\
\hline $\begin{array}{l}\text { INNOVATIVE } \\
\text { MARKET }\end{array}$ & Technology & $\begin{array}{l}\text { Technology } \\
\text { Descarbonization }\end{array}$ & $\overbrace{\text { Descarbonization }}^{\text {Technology }}$ \\
\hline Innovation in value & Descarbonization & Cybersecurity & \\
\hline Value improvement & & $\begin{array}{l}\text { Involvement and } \\
\text { communication }\end{array}$ & $\begin{array}{l}\text { Involvement and } \\
\text { communication }\end{array}$ \\
\hline Imitation in value & Collaboration & Collaboration & Collaboration \\
\hline MARKET & $\begin{array}{l}\text { Institutiona support } \\
\text { and encouragement }\end{array}$ & $\begin{array}{l}\text { Institutiona support } \\
\text { and encouragement }\end{array}$ & $\begin{array}{l}\text { Institutiona support } \\
\text { and encouragement }\end{array}$ \\
\hline
\end{tabular}

Figure 4. Map of perspective. Source: Own elaboration.

It is clear that cybersecurity is a primary issue in the short term, while transparency is considered in the longer term.

Decarbonization (the responsible consumption of fossil fuels and the reduction of $\mathrm{CO}_{2}$ and greenhouse gas emissions), which is now a policy issue across Europe, is increasing over time and is becoming increasingly important.

It should also be noted that collaboration is an important issue when automating a container terminal, as from the private perspective (the terminal operator) there has to be communication and willingness on the part of the port authority (public party), as without a good understanding it cannot benefit the operation.

In addition, collaboration between the parties is essential, as the exchange of data is a basic pillar of automated operations. Therefore, Figure 4 shows that collaboration should increase as time goes by or as it is planned. 
Author Contributions: Study conception and design, A.C.O., J.I.P.S., M.M.E.-I.C. and N.G.-C.; material preparation, data collection and analysis, A.C.O., M.M.E.-I.C., N.G.-C. and J.I.P.S.; writing-original draft preparation, J.I.P.S.; writing-review and editing, A.C.O., J.I.P.S., M.M.E.-I.C. and N.G.-C. All authors read and approved the final manuscript.

Funding: This research received no external funding.

Conflicts of Interest: The authors declare no conflict of interest.

\section{References}

1. Vis, I.F.; De Koster, R. Transshipment of containers at a container terminal: An overview. Eur. J. Oper. Res. 2003, 147, 1-16. [CrossRef]

2. Alho, T. Latest Automation Technology Developments for Ports and Terminals. In Proceedings of the ANESCO Automation Coference, Madrid, Spain, 19 February 2019.

3. Martín-Soberón, A.M.; Monfort, A.; Sapiña, R.; Monterde, N.; Calduch, D. Automation in Port Container Terminals. Procedia Soc. Behav. Sci. 2014, 160, 195-204. [CrossRef]

4. Boer, C.A.; Saanen, Y.A.; Gunther, H.O.; Kim, K.H.; Kopfer, H. Testing, tuning and training terminal operating systems. A modern approach. In Proceedings of the International Conference on Logistics and Maritime Systems (LOGMS), Bremen, Germany, 22-24 August 2012; pp. 25-35.

5. Heilig, L.; Schwarze, S.; Voss, S. An Analysis of Digital Transformation in the History and Future of Modern Ports. In Proceedings of the 50th Hawaii International Conference on System Sciences, Hawaii, HI, USA, 4-7 January 2017.

6. Lee, P.T.-W.; Lam, J.S.L.; Lin, C.-W.; Hu, K.-C.; Cheong, I. Developing the fifth generation port concept model: An empirical test. Int. J. Logist. Manag. 2018, 29, 1098-1120. [CrossRef]

7. Camarero, A.; González, N. Cadenas Integradas de Transporte; Fundación Agustín de Betancourt: Madrid, Spain, 2006.

8. Camarero, A.; González-Cancelas, N. Logística y Transporte de Contenedores; Fundación Agustín de Betancourt: Madrid, Spain, 2007.

9. Geerlings, H.; Van Duin, R. A new method for assessing $\mathrm{CO}_{2}$-emissions from container terminals: A promising approach applied in Rotterdam. J. Clean. Prod. 2011, 19, 657-666. [CrossRef]

10. Zhen, L.; Hu, H.; Wang, W.; Shi, X.; Ma, C. Cranes scheduling in frame bridges based automated container terminals. Transp. Res. Part C Emerg. Technol. 2018, 97, 369-384. [CrossRef]

11. Zhen, L.; Lee, L.H.; Chew, E.P.; Chang, D.-F.; Xu, Z.-X. A Comparative Study on Two Types of Automated Container Terminal Systems. IEEE Trans. Autom. Sci. Eng. 2011, 9, 56-69. [CrossRef]

12. Iris, Ç.; Pacino, D.; Røpke, S.; Larsen, A. Integrated Berth Allocation and Quay Crane Assignment Problem: Set partitioning models and computational results. Transp. Res. Part E Logist. Transp. Rev. 2015, 81, 75-97. [CrossRef]

13. Solórzano, M.C.; Fernández, R.I.; Zambrano, D.C.; Administrativa, V. Plan de marketing en Pymes. In Estrategias Exitosas Para Empresas Comerciales; Universidad Laica Eloy Alfaro de Manabí: Manabí, Ecuador, 2018.

14. Dorado Gómez, S. Proyecto y Estudio de Viabilidad Económico Financiero y Riesgos de Complejo Hotelero y Resort; Universidad Internacional de la Rioja (UNIR): Logroño, Spain, 2014.

15. Iris, Ç.; Christensen, J.; Pacino, D.; Ropke, S. Flexible ship loading problem with transfer vehicle assignment and scheduling. Transp. Res. Part B Methodol. 2018, 111, 113-134. [CrossRef]

16. Morrall, A.; Rainbird, J.; Katsoulakas, T.; Koliousis, I.; Varelas, T. E-Maritime for Automating Legacy Shipping Practices. Transp. Res. Procedia 2016, 14, 143-152. [CrossRef]

17. Agencia Europea Medio Ambiente. Emissions of Air Pollutants from Transport. 2019. Available online: https:/www.eea.europa.eu/data-and-maps/indicators/transport-emissions-of-air-pollutants-8/ transport-emissions-of-air-pollutants-6 (accessed on 26 May 2019).

18. Iris, Ç.; Lam, J.S.L. A review of energy efficiency in ports: Operational strategies, technologies and energy management systems. Renew. Sustain. Energy Rev. 2019, 112, 170-182. [CrossRef]

19. Meyer-Larsen, N.; Müller, R. Enhancing the Cybersecurity of Port Community Systems. In Pharmaceutical Supply Chains-Medicines Shortages; Springer Science and Business Media LLC.: Bremen, Germany, 2018; pp. 318-323. 
20. Resolución del Parlamento Europeo, de 15 de enero de 2019, sobre la conducción autónoma en los transportes europeos (2018/2089(INI)). Available online: http://www.europarl.europa.eu/doceo/document/TA-8-20190005_ES.html (accessed on 6 March 2019).

21. Fondo Puertos 4.0. 2019. Available online: https://www.europapress.es/economia/transportes-00343/ noticia-puertos-espanoles-crean-fondo-25-millones-euros-promover-proyectos-innovadores-logisticos20190408210157.html. (accessed on 24 May 2019).

22. O'Reilly, E.; ESPO. The Infraestructura Investement needs and financing challenge of European Ports. In Port Investments Study; ESPO: Brussels, Belgium, 2018; Available online: https://www.espo.be/media/Port\% 20Investment\%20Study\%202018_FINAL_1.pdf (accessed on 3 February 2020).

23. Venturini, G.; Iris, Ç.; Kontovas, C.A.; Larsen, A. The multi-port berth allocation problem with speed optimization and emission considerations. Transp. Res. Part D Transp. Environ. 2017, 54, 142-159. [CrossRef]

24. OECD. Descarbonising Maritime Transport: Pathways to Zero-Carbon Shipping by 2035. 2020. Available online: https://www.oecd-ilibrary.org/transport/decarbonising-maritime-transport_b1a7632c-en (accessed on 31 January 2020).

(C) 2020 by the authors. Licensee MDPI, Basel, Switzerland. This article is an open access article distributed under the terms and conditions of the Creative Commons Attribution (CC BY) license (http://creativecommons.org/licenses/by/4.0/). 